\title{
World Literature in Estonia: the Construction of National Translation Ethics ${ }^{1}$
}

\author{
KLAARIKA KALDJÄRV \\ KATILIINA GIELEN
}

\begin{abstract}
In addition to many other functions, translating may (and often does) also have a national agenda. Such agenda determines what is going to be translated, how and by whom. Depending on what the national agenda might be, various questions of ethics come into play. Such questions of ethics may be reflected in the translation norms, they may be concealed but still have an important role in constructing the image of translators as well as the idea of what translations should be like.

In Estonia, translation has been of pivotal importance among other things in the formation of the national canon and in developing the Estonian language. In addition to that, translation can be considered to be a means of implementing new ideologies as well as means of resistance. In the present paper, we will ask questions rather than try to answer them: What does ethics of translation mean in the Estonian cultural context? Considering Estonian translation history, can translation ethics be said to be dependent on a particular historical-political situation? And, who has the right to judge translations and the activity of translators?
\end{abstract}

Keywords: translation ethics; literary translation; national translation histories

\section{What do we mean when we talk about 'ethics of translation' and what do we need ethics for?}

In 2001, Andrew Chesterman defined four preliminary types of ethics that he called models of ethics for translators, eventually proposing a Hieronymic oath consisting of nine postulations as a code for professional ethics for translators. The oath was named after the patron saint of translators, Saint Jerome (Eusebius Sophronius Hieronymus) the $4^{\text {th }}$-century translator of the Vulgata version of the Bible. According to Chesterman, it is surprising that that no such oath exists (2001: 149), after all, translation has been deemed to be a 'commissive act' by

\footnotetext{
1 This article was supported by Institutional Research Funding IUT34-30.
} 
KALDJÄRV, GIELEN

Maria Tymoczko (1999: 110), a transaction requiring moral and professional commitment.

The four types of ethics mentioned by Chesterman make it possible to discuss the ethics of translation from four different angles that sometimes overlap, but also contradict at times. What Chesterman basically says is, that these types of ethics depend on the relationship of the translation to the target of translation. However, the question of ethics has not been a very popular subject among translation studies (TS) scholars. This could be conditioned by the fact that despite focussing on the sociology of translations, recent trends in TS have not been able to bring more visibility to and increase the importance of the phenomenon of translation in society in general. Bringing issues concerning translators and translations more to the fore and creating dialogues has been further inhibited by the mistrust of translators themselves in the necessity of theory (see Gielen, Kaldjärv 2016). Peeter Torop, Estonian translation semiotician, has suggested that the development of TS has been disproportionate and that the relationships between history, criticism and theory are disturbed. As a result, the way readers perceive translated literature has become more plain and translated texts have been ripped of their specific nature. According to Torop, researchers are just left to state the fact that it is not only the readers who perceive translations in a distorted manner, but so do the reviewers and critics - people who should explain translational texts to the common readers. (Torop 1999: 42)

Translation studies is a relatively new discipline in comparison with, for example, literary studies and linguistics. We have agreed to consider the foundation of TS as a separate discipline to be the 1972 paper "The name and nature of translation studies" presented by the Amsterdam-based American translation scholar James S. Holmes, since the discipline was named there as TS and its goals as a discipline were defined to be objective, strictly empirical, systematic and non-prescriptive.

Kaisa Koskinen, who is among the first translation studies scholars who has directly taken up the topic of translation ethics, notes (2000: 16), that translation theory has historically been pedagogical and prescriptive in nature. Its main objective has been to create a theoretical basis for the teaching of translation and training of translators in order to achieve 'good' translation results. In such a context a 'good' translation is an 'ethical' translation. However, the question of what is 'good' and can we really talk about 'a good translation' started to interest the researchers. From this question on translation theory has gradually moved away from the concepts of equivalence and fidelity or the attempts to achieve the 'sameness' effect. Instead of normativity and prescriptiveness, the direction taken is that of accepting the differences, describing, analysing and explaining. 
The descriptive branch of the new and thriving discipline of the 1980s and 1990s set the description of real choices by real translators as one of its goals. Although topics such as power, ideology and issues concerning the sociology of translation, topics that seem to be closely related to the questions of ethics, emerged into translation studies already with Holmes' work and the work of his contemporaries, the theorists of translation still did not consider it necessary to turn their attention to the questions of ethics. For instance, Hans Vermeer, a prominent German translation scholar lumps morals and ethics into a category of 'personal questions' that should not be dealt with by the theory of translation: ethics and morality are "phenomena concerning personal behaviour" and therefore should not be included in the general theory which should be kept value-free (Vermeer 1996: 83). Furthermore, Gideon Toury's (1995a) translation norms that determine the right and wrong translational behaviour in a given culture at a given moment in time very often seem to be closely related to questions of ethics, yet the issue is not dealt with. As for the reason for the lack of interest in the ethics of translation, Koskinen (2000: 76), whose doctoral dissertation took the subject of translation ethics under closer observation, suggests that it would bring along problems that could spoil the image of the objective, strictly empirical, systematic and non-prescriptive discipline.

In the early 2000s, however, there was a surge for translation ethics that resulted in a special issue of The Translator (7/2001). The editor of the volume, Anthony Pym (2001: 129) claims in the introduction to the volume that TS has returned to the question of ethics, but from a different angle and with a different reason than the fidelity and equivalence issues of the 1960s and 70s. He considers the return to the topic not to be directly associated with translation but rather with general social trends - globalizing economies, outbreaks of nationalisms, cross-cultural communication and the spread of the Internet. Apart from Pym, also the work of Lawrence Venuti has been partly associated with ethics in the field of translation studies. For Venuti, translations serve to foster the understanding and acceptance of cultural differences, and this is also the basis of his concept of translation ethics. Thus, according to Venuti, a translation method should be chosen keeping in mind the context of translation, its time and place. Venuti's ethics is not based on the fidelity to the client nor to the original, but on an intelligent cultural exchange, on cultural difference. (Venuti 1998:188) Pym, on the other hand, looks at translators as agents being between two cultures who benevolently and in a neutral manner help conduct communication processes. He is critical of Berman's idea of retaining the 'otherness of 'the other' because this would turn the translator into a customs official who does not allow the foreigners to assimilate in the target culture (Pym 1997: 15). Pym's ideal translator interculturalizes. The translators are 
KALDJÄRV, GIELEN

not just messengers and thus their ethical responsibility begins already with the question Shall I translate? When the question has received a positive answer, the translation result must be accepted in any of the cases (Pym 1997: 99-101). According to Pym, the translator has to be loyal to the intercultural space, but Koskinen (2000: 77), for example, doubts that there is a large community of such neutral translators who do not have a preference in either of the cultures. Nevertheless, there is a substantial difference between Pym and Venuti: Pym's goal is to retain the illusion of sameness, although he knows that this is an illusion and attempts to disguise it with professionality and anonymity. Venuti, on the other hand, attempts to demolish the illusion of sameness without asking whether it is possible or not (see Koskinen, ibid.).

The issues raised by both Venuti and Pym, issues regarding visibility or invisibility of the translator and achieving trustworthiness in translation are closely connected to the question of ethics. Koskinen (ibid.) asks whether translators have the right to do whatever they choose provided they openly place the cards on the table the way both Berman (1995) and Venuti (1995) seem to propose? She presumes that even though visibility and openness have more possibilities to create the impression of credibility than simply concealing oneself behind the mask of professionalism, we cannot claim visibility to be more ethical than invisibility/anonymity (or vice versa) since this still depends on the concrete translational situation. The problem to be solved is not in making the translator more visible, but rather in changing the attitude towards such visibility of the translator that has so far been regarded as something derogatory by the public.

Koskinen (2000: 14) claims that when it comes to translation, there are more options to choose from nowadays and thus the translator has more power to decide, which in turn means that the translators have to take more responsibility for their activities. Translation ethics would therefore also be an attempt to assess and justify the choices made and actions taken by individual translators. For example, the translator has to decide whether to proceed according to the existing norms or deviate from them. In other words, does the translator decide to take part in the process of changing the existing norms? (Ibid. 15) Koskinen says that "If any decision includes moral aspects, it follows that any act of translation, and any theoretical treatise on it, can be read from the point of view of ethics" (ibid. 16). Translation is both an individual as well as a societal activity and ethics of translation is first and foremost responsibility, also responsibility towards other translators. Translators inevitably position themselves into a historical context and think of what they want to achieve and by which means. (Ibid. 108) Visibility therefore means that translators know what they are doing and are capable of explaining that to others as well. (Ibid. 114) 
World Literature in Estonia: the Construction of National Translation Ethics

According to contemporary theories, manipulation is considered to be a part of translation process, that means, there are always somebody's interests at stake. This must make raising questions concerning the ethics of translation even more justified. Hence, proceeding from the above, ethics should definitely have a place in translation studies. The next step would be to ask how to approach it? Could it be that various different ethics of translation exist? Indeed, from the contemporary point of view there is no fixed translation ethics, there are different times, situations, commissions, target groups etc.

Spurred by the resurfacing of the topic at the beginning of the 2000s, we will look at Anthony Chesterman's (2001) attempt to classify the types of translation ethics that may become dominant in certain translational situations. According to Chesterman, there are four models of translation ethics.

- Ethics of representation - the idea of ethics lies in the fidelity and truth here. The ethical imperative is to present the mirror image of the original (transparency), in which the author's intention is conveyed without adding or omitting or changing anything.

- Ethics of service - means compliance with the instructions by the client and is characterized by the loyalty to the client. In this model the translator has behaved ethically if the translation fulfils the criteria set by the client (be it then omitting or adding or changing).

- Ethics of communication - in this model the ethical goal of the translator is intercultural cooperation between parties that are 'other' to each other, translator is seen as a mediator working to achieve understanding.

- Norm-based ethics - means behaving as one is expected to behave, not surprising the reader or the client. This model is connected to the translation norm theory by Gideon Toury, who says that the behaviour of translators is determined by the existing sociocultural norms of translation in a given society at a given point in time.

Chesterman arrives at a similar viewpoint that had been reached before by the great descriptivist and translation norm theoretic Gideon Toury himself, who has defined translation in the following manner: "a translation is a fact of whatever target sector it is found to be a fact of " (Toury 1995b: 140). In other words, translation is what we consider translation to be in a specific time and space. Therefore, perhaps we could address the topic of translation ethics in a similar manner stating that ethical translation is what we consider it to be in a particular location at a particular time and under particular circumstances. When looking at a specific commission, specific act of translational communication or specific moment in time and specific socio-cultural context, we need to talk about a specific ethics of translation. Hereby, we are back at the question of a translation 
KALDJÄRV, GIELEN

that is considered to be 'good' or serve the purpose in the eyes of a translator, editor, publisher, reader or a receiving culture. What is a matter of ethics, is rather the decision to openly state what is 'good' or 'bad' in each of such cases.

\section{In search of ethics in Estonian translation history}

Estonian translation history, although short in comparison with centralEuropean cultures, has nevertheless shown many trends and tendencies. It has been suggested that Estonian culture is a translated culture (referring to 300 years of translations before the emergence of original Estonian authors and texts). Thus, it is important to understand the role of translation and the proportion of translation in Estonia. According to different sources and regarding different time periods, translations amount to $90 \%$ of the published philosophy, science and literary output. Translation has more often than not had the aim and function of developing, perfecting, renewing Estonian culture, language and literature. Jüri Talvet (2005: 439) stresses this function of translation: "a small but strong group of top Estonian writers in the 1920s devoted much of their energy to the mission formulated by Ants Oras - building Estonian language and literary culture with the help of mediating world literature. [...] they united the roles of translating and introducing-analysing world literature. There were constant attempts to connect and compare world- and developing Estonian literature. As such translation has been connected to powerful and opinionated personas in Estonia, who have taken up the mission of enlightenment (developing language and literature). Let us call them translation missionaries."

The aim or principle of developing the local culture (always implicitly marked as 'lesser' or 'inferior') has in its turn determined the canon of translated works, since not all the texts are suitable or purposeful from the point of view of such a mission. Translations should fill the blank spots, be the so-called gap fillers in the cultural scene. In the following, we will bring some examples. Ott Ojamaa (2010 [1969]: 62-63), one of the Estonian translation missionaries, has said that when translating Estonians should set the priority to be cultural gain: “...we try to translate literature that is as different as possible, not such literature that already exists here. What is very important is the principle that we must translate only for ourselves, taking into account the state our own literature is in. Only then can we produce translational literature that is worth something. [...] It has to exercise only those possibilities of language that no Estonian work of literature would address. Satisfy those needs that would otherwise be dissatisfied."

2 Quotes translated by the authors of the article. 
Almost forty years later, Märt Väljataga (2006) an Estonian literary scholar and translator is of the opinion that some languages and poetries are small and their grip is weak, and therefore they need to bring in additional force from outside: "A small language and poetry has simply not sufficient inner development resources. The vehicle for change often comes from outside, from translations. [...] It is worthwhile translating poetry for the sake of Estonian poetry, in order to expand its possibilities. In such cases the adequacy of translation is not that important either." Although the last quote concerns poetry, we can assume that the position is similar when it comes to prose: in case of a small and young literary culture, we must keep in mind the gains from translation and therefore manipulations concerning translational texts are understandable and even justified if they further the mission of enriching the target culture. Elin Sütiste has said, analysing Tiit Hennoste's postulations about the world view of the literary group of the beginning of $20^{\text {th }}$ century Young Estonia, that these postulations reveal on the one hand a utilitarian attitude to translation as cultural borrowing and on the other hand an inferiority complex: we must borrow to become original; translations are valuable not by themselves, but only as steps to the original. (Sütiste 2012: 157). All in all, we have reason to conclude that Estonian translation history is in a great part the history of Estonian language and literature.

\section{Borrowing from the 'other', trends in Estonian translation history}

The nature of translation norms that operate in a culture has its origins in history and the importance of translation in the formation of Estonian literary language and the development of literature has influenced the prevalent translation methods during certain periods in history. Three or four main periods and trends of prevalent methods have been noted. For example, in early bible translation, from the $16^{\text {th }}$ century onward, that were for a long time the only Estonian language written documents, the language was heavily based on other, more developed literary languages used in the region, such as German and Latin. This period can be considered a period of developing literary Estonian by people whose mother tongue was not Estonian (mostly Baltic Germans) based on languages that differed considerably from the Finno-Ugric languages. Such a period can be seen to extend from the first written translational document in Estonian that has come down to us, the so called Kullamaa manuscript (15241532) containing the translation of Pater Noster, until up to the $19^{\text {th }}$ century national awakening. 
KALDJÄRV, GIELEN

The $19^{\text {th }}$ century literary activity in Estonia has been characterised by publishing adaptations, the goal of which was to educate and entertain the gradually developing Estonian readership. The first decades at the beginning of the $20^{\text {th }}$ century translational activity in Estonia explicitly started serving the emerging national goals - language and cultural renewal. Ülar Ploom (2011: 215), for example, leaves aside the early period of the translation of biblical texts and elicits four more or less distinct periods in Estonian translation history: a period of translational adaptations (that he calls 'accommodations') of the $19^{\text {th }}$ century; a period of language and cultural renewal initiated by a literary formation by the name of Young Estonia (early 1900s); a period of ideologically resistant and linguistically conservative translations during the Soviet period; and a period of discourse-aware translations starting from the 1990s.

Hasso Krull (2011: 114) brings out a trend in Estonian cultural history starting from the early 1900s that concentrates on the search for a standardised translation language. First and foremost, for the written Estonian not to look like German translations. The most prominent and successful Estonian language ideologist who planned to create an Estonian language that would read similarly regardless of the language of the original was Johannes Aavik (1880-1970). The search for such an ideal language can be seen throughout the 1920s and 1930s in translation criticism published mostly in the literary journal Eesti Kirjandus that was a platform for discussions about literary phenomena and where translators and literary figures such as Johannes Aavik, August Palm, Johannes Semper, Marta Sillaots etc., held heated discussions regarding the matters related to 'good' Estonian translation language: loan words, foreign sounding sentence structure, style of translation and so on. Yet, due to wars and turmoil during the first half of the $20^{\text {th }}$ century, such a standardised translation language emerged only in the 1960s or 1970s. According to Krull (1998: 82), fixed principles emerge regarding how to construct a translational sentence, what kind of losses in translation are acceptable and how much can be added by the translator. The Soviet period (1940 - 1991), brought along a sudden rise in the publishing of translated literature in comparison with Estonian own literary output. During the process, translations become unified, translational language standardised. The rise in the numbers of translated literature during political and ideological changes can be explained by the dynamics between literary systems explained in Itamar Even-Zohar's poly-system theory. Even-Zohar (1990: 47) says that the choice of literature to be translated depends on the principles of the target environment: "...the texts are chosen according to their compatibility with the new approaches and the supposedly innovatory role they may assume within the target literature." Even-Zohar goes on to bring out three conditions for the rise of translation in a literary system: “... three major cases can be discerned, which 
are basically various manifestations of the same law: (a) when a poly-system has not yet been crystallized, that is to say, when a literature is "young," in the process of being established; (b) when a literature is either "peripheral" (within a large group of correlated literatures) or "weak," or both; and (c) when there are turning points, crises, or literary vacuums in a literature." (ibid. 47) Regarding Estonia of the first half of the $20^{\text {th }}$ century, especially during the ideologicalpolitical turning point in the 1940s, when Estonia became part of Soviet Union, the local literary environment met all three possible manifestations of the EvenZoharian law: the translation poly-system was by no means firmly established (a), the literature can be characterised as peripheral (b), and, most importantly, there was a historical turning point or a crisis that resulted in a vacuum (c).

Although the decades following the Second World War could be considered as a vacuum, Jaak Rähesoo (2014: 7) regards the 1950s and 1960s in Estonia as an important period in the internal development of translational practices, during which a model principle was established to pursue the sense of the original and create a more free artistic impression of it. From there on, according to Rähesoo, Estonian translation will follow what can be called 'the normality model' in the contemporary world that is conservative when it comes to translation. Although unrecognised at times, this model has its own problems: on the surface this idea needed a more intuitive and thus subjective approach that was difficult to formulate. In practice, however, the expectation was still that the intuitive choices of the translator would lead to a unified/standardised result. The compromises and problems inscribed to this 'normality model' were hard to admit. This was also already conditioned by the general state the Estonian language was in: the normative attitude of the 1930s gained force from a surprising source - on the one hand, a Soviet distrust towards everything unregulated and experimental and on the other hand, the nationally minded language preservers who tried to fight the Russian influences both in language and in mentality. Thus, when it came to actual choices translators had to make, they opted for the 'golden mean', avoiding extremes. (Ibid.) What we have here is, firstly, a fear of extremes of the ruling Soviet ideology and, secondly, the protection of the pureness and norms of Estonian. Such a situation created a translation norm that allowed to approach the source (prose) text more freely and subjectively yet established stricter norms for the language of translation. The expected result was a translation that uses a standardised, well-sounding Estonian. Rähesoo points out that throughout decades the readers have been trained and their expectations are based on this so called 'normality' model. Anne Lange (2007: 12) describes the period, the beginning of the second half of the $20^{\text {th }}$ century, in a similar idiom: being cornered politically, our cultural backbone was maintained by translating. Language editors were regarded as the 
KALDJÄRV, GIELEN

guardians of correct language and a translator had little choice when it came to the lexico-grammatical choices of the translation language.

Estonian re-independence has enabled us to question the prevailing norms that gained ground during the Soviet era. At the beginning of the 1990s, the translation scene gets more diverse as to the techniques of translation. Experimental translations start appearing, mainly in the field of translation of philosophy and poetry, but also elsewhere. Since there is no political censorship any more, it is possible to translate and publish almost everything. However, in market-liberal economy control mechanisms can now be seen elsewhere. Books are published in galore, but only a small amount of them earns profit for the publishers and thus a large part of translated literature (but also other literature and culture in general) is published with the help of the Cultural Endowment of Estonia, a foundation for the support of arts and culture based on the state budget, donations and investments. Despite of the rotation of the members of the expert groups who decide the allocation of money, it is very possible that such a system of distribution of funds does have a certain influence on the translational scene in Estonia, especially when taking into account that the norms described above have deeply infiltrated culture and thus become self-evident. Principles of the allocation of funds are an issue that is directly connected to translation ethics as well as handing out annual monetary awards in all the cultural spheres, including literary translation. Such awards directly point to the 'good' translations, yet Märt Väljataga, the chairman of one of the award committees, has revealed to a journalist that the process of awarding does not include the reading of all the nominated translations by all the members of the board and established criteria for determining the 'goodness' of a translation do not exist. The committee could not possibly have time for that. He says that when making the decisions whom to award, the committee considers the translators' previous achievements: novices would not have a chance unless they have translated something extremely valuable and difficult. (Larm 2017)

The function of translations in a culture at a given point in time is in correlation with the translation method of the accepted translation norm. As translations have historically had the function of enrichment of the culture in Estonia, i.e. carried by the mission of developing Estonian language and literature, two curious trends appear regarding the translation of different genres since the stabilization of the translation language from the 1960s onward. Firstly, a prevalent trend in the translations of poetry considers retaining the format and meter of the original more important than conveying the content (narrative structure, precision of terms and descriptions). Secondly, prose translations experience almost the opposite: content is held more important than the form. (See also Kaldjärv 2017.) The existing translation norm requires adherence to 
the orthographic and grammar rules of Estonian (to avoid contaminating the language with foreign influences), the text should be fluent to read and seem natural as it were originally written in Estonian. Translations deviating from that norm are difficult to accept. Equivalence on the plot level is valued but not on the level of rendering the idiosyncratic language of the original author.

According to Venuti (2005: 178): “... nations do indeed "profit" from translation. Nationalist movements have frequently enlisted translation in the development of national languages and cultures, especially national literatures." Venuti says that the forms taken by such [nationalist] translation agendas vary with the social situations in which they are deployed, and their varying approaches to foreign texts and cultures may be diametrically opposed, seeking either to preserve or to erase linguistic and cultural differences. Yet in both cases the differences of the foreign texts are exploited to construct a national identity that is assumed to pre-exist the translation process. (Ibid.) Venuti goes on to say that "...nationalist translation agendas depend on the same circularity: the national status of a language and culture is simultaneously presupposed and created through translation. Insofar as such agendas implicitly reveal the incompleteness of the nation, translation is a scandal to nationalist thinking, providing yet another motive for indignation and offense, for perceiving a translated text as an international act of violence."

Berman (1984: 226-249), Pym (1997: 88) and most of all Venuti (1991: 129; 1995: 99-118), have all proceeded from German Romanticism, first and foremost Schleiermacher's input as the introducer and propagator of the socalled foreignization method in translation. Yet when Berman stresses the ethical contribution of Schleiermacher's work, its willingness to encompass the foreign, Venuti is more critical, saying that Schleiermacher's method can be called ethnocentric instead. (Venuti 1991: 129) This means that instead of opening up to the cultural 'other', such a translation method makes good use of it in constructing their own culture. Despite the differences of Berman, Pym and Venuti in their attitude towards Schleiermacher they all seem to agree that the national component is an undesired element in translation and translation theory in general. Koskinen (2000: 49-50) asks, however, whether avoiding the national element in translations is possible at all and even necessary? 
KALDJÄRV, GIELEN

Conclusion: Questions of ethics in a translational context in which the function of translation has been connected to the national agenda

Norms originate from the (national) function and ethics of translation. Keeping in mind the Estonian case, then from the models of translation ethics proposed by Chesterman we can talk about the ethics of service, provided we change the term to cover historical periods rather than only individual translators. According to Chesterman: "A translator is deemed to act ethically if the translation complies with the instructions set by the client and fulfils the aim of the translation as set by the client and accepted and negotiated by the translator." (2001: 140). In our case, we have an imaginary client, a missionary of translation that keeps an eye on the language and culture of a small nation, a client who sets, fixes and safe keeps the norms of translation. Ethics of service make the loyalty to be the 'prime quality' of a 'good translator-servant' (Chesterman 2001: 140). The translators are loyal first and foremost to the client, but also to the original writer and the target readers serving and catering for their expectations. However, we can also talk about Chesterman's norm-based ethics in Estonian case. Toury's translation norms determine what an acceptable translation product should look like in a given culture at a given moment in time. Norms thus represent the expectations target culture has regarding translations as well as reflect the values of the target culture. According to Chesterman, "behaving ethically thus means behaving as one is expected to behave, in accordance with the norms, not surprising the reader." (2001: 141). Estonia has had a program for translation and missionaries of translation who stand for the execution of the program. Ethics, be it then ethics of the service or norm-based ethics is seldom, if not never, discussed. In defining translation ethics, we are inevitably stuck in a concrete translational situation, at a particular point in time in a particular place for a particular purpose and target audience. Thus, if translation can be defined to be what we think translation is, it is legitimate to claim that translation ethics is what we consider translation ethics to be.

\author{
Klaarika Kaldjärv \\ klaarika.kaldjarv@ut.ee \\ Tartu Ülikool \\ Lossi 3-420 \\ 51003 Tartu \\ EESTI / ESTONIA
}


World Literature in Estonia: the Construction of National Translation Ethics

\author{
Katiliina Gielen \\ katiliina.gielen@ut.ee \\ Tartu Ülikool \\ Lossi 3-303 \\ 51003 Tartu \\ EESTI / ESTONIA
}

\title{
References
}

Berman, A. 1984. L'épreuve de l'étranger: Culture et traduction dans l'Allemagne romantique: Herder, Goethe, Schlegel, Novalis, Humboldt, Schleiermacher, Hölderlin. Paris: Gallimard.

Berman, A. 1995. Pour une critique des traductions: John Donne. Paris: Éditions Gallimard.

Chesterman, A. 2001. Proposal for a hieronymic oath. - The Translator, 7(2), 139-154.

Even-Zohar, I. 1990. The Position of Translated Literature within the Literary Polysystem. - Poetics Today, 11(1), 45-51.

Gielen, K., Kaldjärv, K. 2016. Method and Theory: On the Compilation of a Collection of Texts in Estonian Translation History. - Interlitteraria, 21(1), 35-50.

Kaldjärv, K. 2017. Tõlkija kui nähtamatu maag: näiteid hispaaniakeelse kirjanduse tõlgetest Jüri Talveti tõlkemõtte valguses. - Methis. Studia humaniora Estonica, $17 / 18,70-93$.

Koskinen, K. 2000. Beyond Ambivalence: Postmodernity and the Ethics of Translation. Tampere University Press: Acta Universitatis Tamperensis.

Krull, H. 1998. Mõtete tõlkimine. - Keel ja Kirjandus, 2, 81-85.

Krull, H. 2011. Gilgameš tuleb maailma otsast. - Vikerkaar, 3, 114-117.

Lange, A. 2007. The Poetics of Translation of Ants Oras: abstract. Tallinn: Tallinna Ülikool.

Larm, P. 2017. Mõttekirjandusel oma auhind. - Sirp, 03.02.

Ojamaa, O. 1969. Kümnenda muusa muresid I. - O. Ojamaa, Armastus seaduslikus abielus. Tartu: Ilmamaa, 54-71.

Ploom, Ü. 2011. From Mugandus [Accommodation] towards Discourse-Aware Translation: Some Aspects of an Italian Itinerary in Estonian Translation History. A. Chalvin, A. Lange, D. Monticelli, eds., Between Cultures and Texts. Itineraries in Translation History. Entre les cultures et les textes. Itinéraires en histoire de la traduction. Frankfurt am Main etc.: Peter Lang, 213-226.

Pym, A. 1997. Pour une éthique du traducteur. Arras \& Ottawa: Artois Presses Université / Presses de l'Université d'Ottawa.

Pym, A. 2001. Introduction. - The Translator, 7(2), 129-132.

Rähesoo, J. 2014. Tõlkimise probleemsus. - J. Kaus, T. Tamm, eds., Tõlkija hääl. Eesti Kirjanike Liidu tõlkijate sektsiooni aastaraamat. Tallinn: Eesti Keele Sihtasutus, 6-8. 
KALDJÄRV, GIELEN

Sütiste, E. 2012. Tõlkelugu ja kultuurimälu. - Methis. Studia humaniora Estonica, 9/10, $152-162$.

Talvet, J. 2005. Maailmakirjanduse kodustamise küsimusi. - Keel ja Kirjandus, 6, 433-441.

Torop, P. 1999. Kultuurimärgid. Tartu: Ilmamaa.

Toury, G. 1995a. The Nature and Role of Norms in Translation. - G. Toury, Descriptive Translation Studies and Beyond. Amsterdam; Philadelphia: John Benjamins, 53-69.

Toury, G. 1995b. The Notion of 'Assumed Translation' - An Invitation to a New Discussion. - H. Bloemen, E. Hertog \& W. Segers, eds., Letterlijkheid, Woordelijheid / Literality, Verbality). Antwerpen/Harmelen: Fantom, 135-147.

Tymoczko, M. 1999. Translation in a Postcolonial Context. Early Irish Literature in English Translation. Manchester: St. Jerome Publishing.

Väljataga, M. 2006. Milleks tõlkida luulet. - Eesti Päevaleht, 04.03.

Venuti, L. 1991. Genealogies of Translation Theory: Schleiermacher. - TTR, VI, 2, $126-150$.

Venuti, L. 1995. The Translator's Invisibility. A History of Translation. London and New York: Routledge.

Venuti, L. 1998. The Scandals of Translation. Towards an Ethics of Difference. London and New York: Routledge.

Venuti, L. 2005. Local Contingencies: Translation and National Identities. - S. Bermann, M. Wood, eds., Nation, Language and the Ethics of Translation. Oxford, Princeton: Princeton University Press, 177-202.

Vermeer, H. J. 1996. A skopos theory of translation (Some arguments for and against). Heidelberg: TEXTconTEXT. 